\title{
The Regulation of Pedestrian Path on Corridor Jamin Ginting Street Berastagi District
}

\author{
Novrial "and Hamdani \\ Architecture Department, Faculty of Engineering, Universitas Sumatera Utara, Medan, \\ Indonesia \\ *email: novrial@usu.ac.id \\ Submitted: 14 January 2020 Revision: 22 January 2020 Online: 29 January 2020
}

\begin{abstract}
Generally, the target of road corridor construction is to provide a quality pedestrian, give comfort to pedestrian as user of road corridor. In create a good regulation of pedestrian path, it is necessary full of rules and requirements as to improve comfort for user of road. The factors influence to physical comfort of pedestrian path are circulation, smell, bench, security and beauty. The location of this research is Jamin Ginting street between Monument Pahlawan with Monument Kol, Berastagi which it is often pass by tourist. However, the condition on pedestrian path at this region, there have not some requirements to create a good pedestrian path. The objective of research is to plan regulation of pedestrian path on JaminGintingstreetBerastagi, according to requirement to Iswanto and the Rule of Minister PU No. 03/PRT/M/2014 on pedestrian path. The method of research is descriptive research, and then it compares with requirements and rules after that the conclusion is Comfortable is included circulation, smell, bench, security and beauty on pedestrian path at Jamin Ginting street Berastagi do not have qualified according to Iswanto and rules Minister PU No. 03/PRT/M/2014 on a good pedestrian path. This research proposed a recommendation of design pedestrian path according to Iswanto and Rule Minister No 03/PRT/M/2014 on pedestrian path at Jamin Ginting street Berastagi.
\end{abstract}

Keywords: pedestrian path, pedestrian, physical comfort

\section{INTRODUCTION}

The regulation of a corridor of city is an important part of city plannings. The regulation of a corridor is also very important to improve the physical quality of the corridor space and the area of city has declined. On the corridor of the road, there is a pedestrian path that function as a tool circulation and human activity. Berastagi is a city that located in te regional mountain, exactly on Karo District, North Sumatera. Berastgai is also known as the city of tourism because there are many recreation places who are often visited.

One of the corridors in Berastagi have potentially views the beauty of city is JaminGinting street, between Monumnet Pahlawan until Monument Kol, because the road is downtown of Berastagi which is very often pass by the tourist.

This corridor can connect to area of Mejuah-juah Garden, Gundaling Hills and also Berastagi fruit market. However, the show of situation on pedestrian path in area between Monument Pahlawan until Monument Kol, there have some not some requirements to create a good pedestrian path. On the pedestrian path located at Berastagi corridor, there are some point of narrow path and also it damages on the surface pedestrian path. Sometimes pedestrians still feel less comfortable due to lack of facilities on pedestrian path, such as there is no rest area with provides benches, at least of tree, and feel less secure because of there is no road light at night.

Pedestrian come from Greek that is "pedos" means "foot", so it can be interpreted as pedestrian or person who walk. Meanwhile road is a media on the Earth which it makes human to easy walk. Therefore, pedestrian have the meaning is the process of human move from one place to another place by foot, so the pedestrian path can be united with the environment. Pedestrian: Pedestrian is people who walk. In another meaning, pedestrian is people who do activities by foot. In this research, pedestrian is people who do activities by foot at region along Jamin Ginting street Berastagi. Pedestrian Lane: The function of pedestrian lane is adjusted to urban 
development as the facility for pedestrians, urban splendor, social, interaction media, urban conservation facility, the place for relaxing, and connection with the other kinds of mode. The standard of pedestrian lanes is concerned with their width, height, and facilities. Physical Comfort: Physical comfort can also as a pleasure and satisfaction of human on doing activities. The factors influence to physical comfort of pedestrian paths according: Circulation: For the pedestrian, it is should be considered in the comfort, because circulation is very closely related with activities placement pattern so that the movement of space from one place to another place. Smell: It is also influence the level of pedestrian comfort at doing activities on pedestrian path, especially on area of garbage disposal then the not good smell will smell by person through it. Placement of the bench : The outside of path from circulation is very important, because activities doing on the pedestrian path is not only walk but also use to socialization. The bench is also able to improve the comfort for pedestrian who tired and want to rest. Security: The most important on the pedestrian path is road light. The purpose of road light is to lighting at night, because it can make pedestrian fell comfort and secure and the contrst if there is no road light can trigger crime (criminal). Beauty: It's difficult to judge a beauty. Every people have different perceptions for something is beautiful. However on the comfort, beauty can take in terms arrangement of plant [1].

\section{METHODS}

The method used in research is descriptive method. Descriptive method is to describe condition subject or object of research based on the facts or reality at now. Descriptive research is only explain the situation or event of research. The researcher only act as observer, observe symptoms and note symptoms on the book of observation.

\section{RESULTS AND DISCUSSION}

Pedestrian physical comfort will be analyzed by compared with requirements and rule of Minister PU No. 03/PRT/M/2014. The analyze includes the condition of pedestrian path from circulation, smell, bench, security and beauty. (1) Circulation: The pedestrian path located on Jamin Ginting street Berastagi has average width 5 meters but there is narrow path in some points. Pedestrian path at Berastagi is a regional store that have 5 meters wide along the pedestrian path. But in some point area occur narrow path so on the path is smaller not fill dimensions based on the region and environment (figure 1) [2].

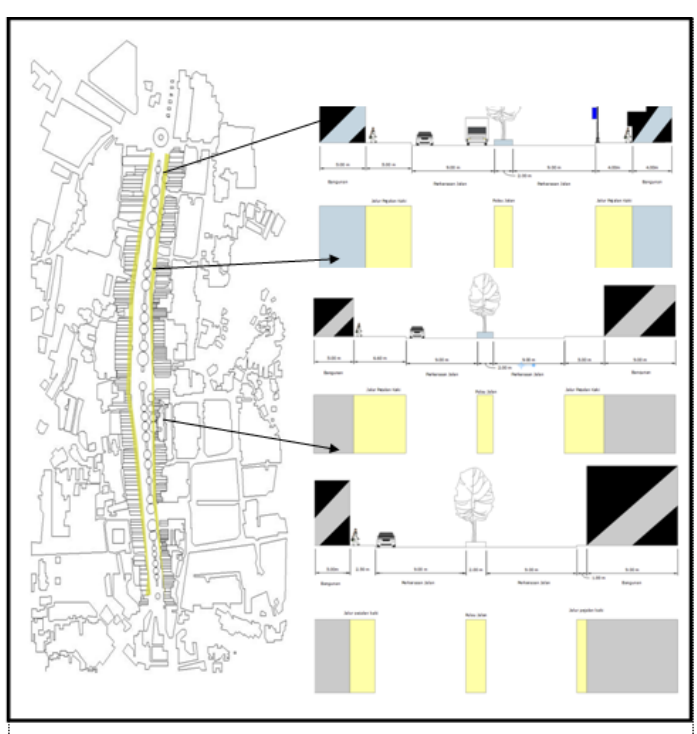

Figure1. Buildings Surrounding Pedestrian Lane

\section{Smell}

Smell can also influence level of pedestrian comfort in doing activities walk on pedestrian path, especially on area of garbage disposal therefore the not good smell will be smell by person through it. Based on rules of Minister PU No 03/PRT/M/2014 mentioned that the garbage located free outside of the pedestrian path with the distance between 20 meters from garbage to another. The trash made with dimensions as needed, and use materials have high durability such as metal and print concrete. The pedestrian path located on Jamin Ginting street, Berastagi, the trashuse material of bamboo. So it is easily damage and the garbage scattered if the trash broke. The placement of trash is also place on the edge of the pedestrian path, and it makes not good views. Based on maintenance, the trash has been full and it have not been appointed by cleaning officer so that causes not good small if left too long (figure 2) [2]. 


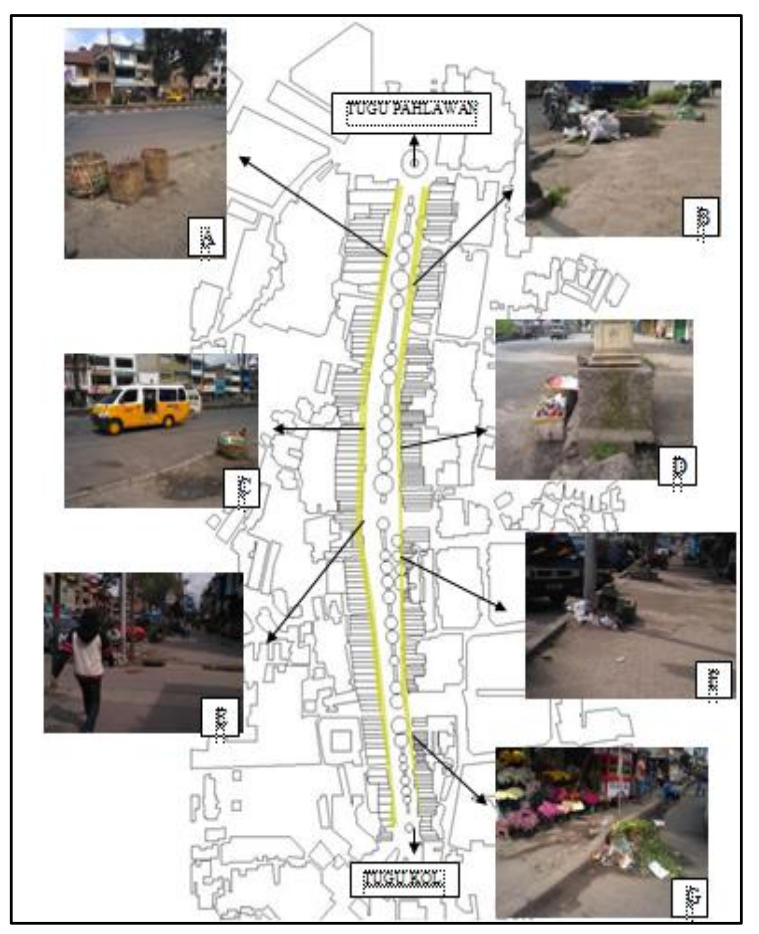

Figure 2. Picture points of garbage collection on pedestrian path

\section{Bench}

Requirement of good pedestrian path should be have rest area that it made at certain distance and adjusted to the scale of the distance on comforts walk. But on the pedestrian path Jamin Ginting street, Berastagi, there is no rest area, no bench for pedestrian so it reduce comfort for pedestrians. Pedestrians only benefit of comfort area to rest, such as sit on the flower pot and sit on th green line barrier. It is shows pedestrians is uncomfortable due to in rules PU No. 03/PRT/M/2014 should be serve bench for pedestrian on space is 10 meters from one to another (figure 3) [3].

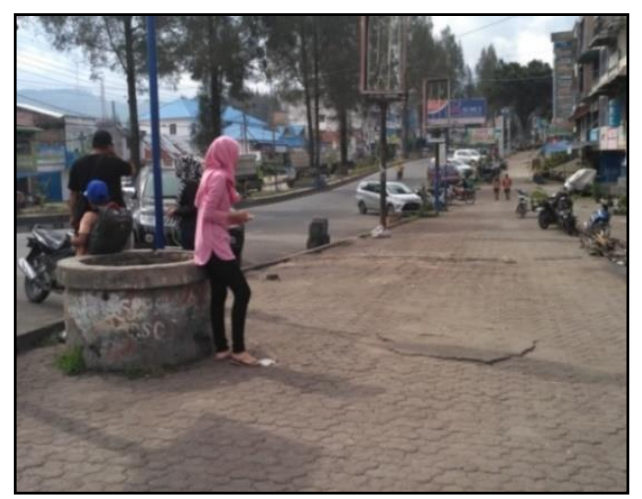

Figure 3. Pedestrian sit on the flower pot

\section{Security}

Based on the requirement PU No. 03/PRT/M/2014road lights should be on the pedestrian path. It is on space is 10 meters from one to another and the power is 75 watts. On the pedestrian path at Jamin Ginting street, Berastagi there is no road lights so that makes pedestrians disrupted at night. The lighting used to light the path only benefit of light by store lamps (figure 4) [2].

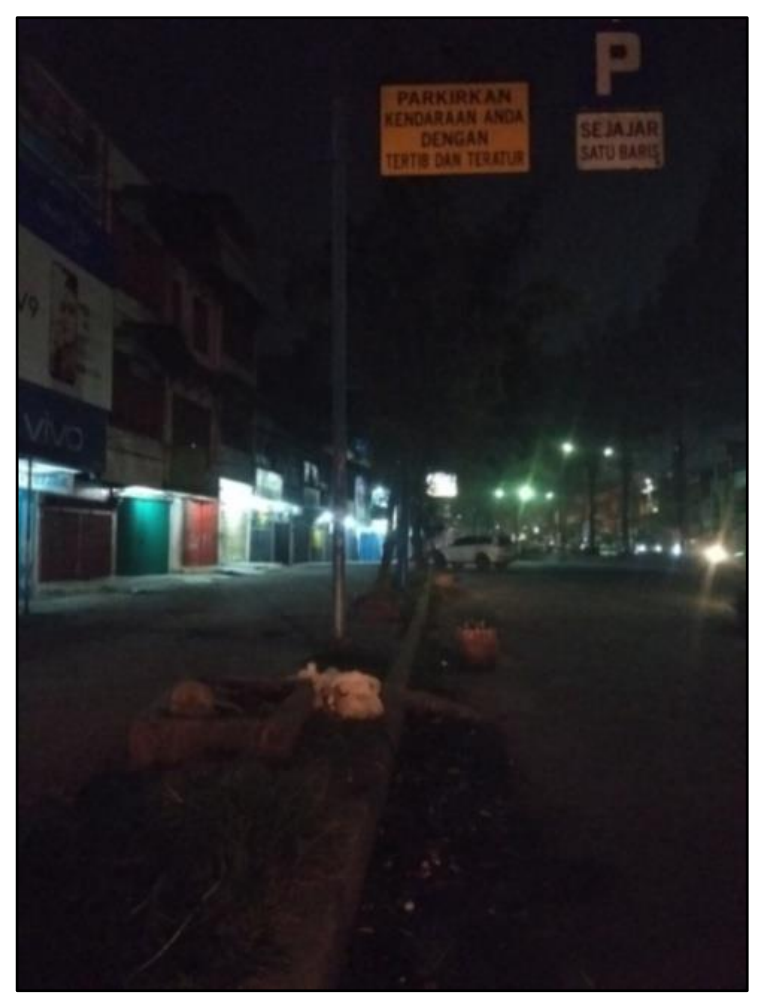

Figure 4. Condition pedestrian path at night.

\section{Beauty}

The condition vegetation of plants and flowers is less maintained, flowers pot and trees is not organize position on pedestrian path at Jamin Ginting street Berastagi. According to requirements, a good pedestrian path should have a planting types of certain plant as a place of protection from sunlight and shedder for pedestrians. The mahogany tree on the pedestrian path is only some at corridor and the condition is less maintained. It makes shade of the pedestrian path are very less. Trees on side road is only flea needle of trees that it is feels less as a shedder tree. Complied requirements of good pedestrian paths in terms of 
maintenance because on the plant is no sprinkling water, fertilization and pruning to plant (figure 5) [3].

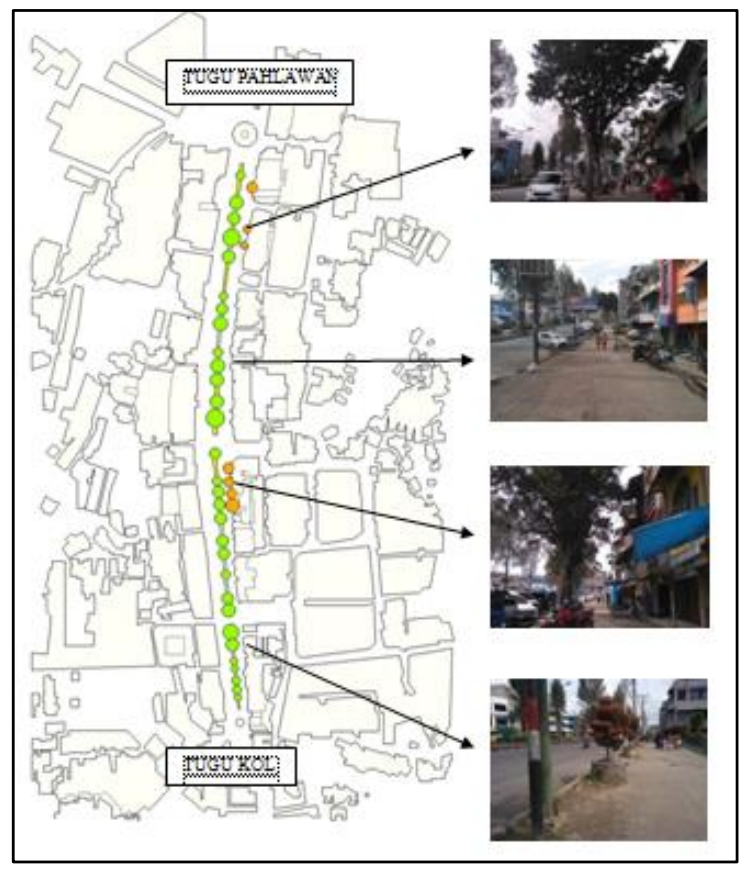

Figure 5. Picture point of trees on the pedestrian path

\section{CONCLUSION}

According to Iswanto and Regulation of Minister of PU No 03/PRT/M/2014, the comfort include circulation, smell, bench, security and beauty on pedestrian path at Jamin Ginting street Berastagi has not qualified for good pedestrian path. The circulation path on pedestrian path does not qualified the standard of dimension based on environment and region. The smell, trash is still using the bamboo that it is easily damaged and placed on the edge of the road that cause not good smell. The bench is not available on the pedestrian path reduces comfort for the pedestrians who want to rest. The security on pedestrian path on Jamin Ginting street Berastagi, is very concern because it is not road light on the path [3].

Then, it makes pedestrian disrupted because the path will be dark and it can provoke criminal acts. The beauty of pedestrian path is not seen, because it's less shedder tree and also ornamental plants. So, Berastagi which should be famous for its coolness of air, it is not delivered by a wasted pedestrian path.

The suggestion that can give to next study as follows: (1) The variable of comfort can be add with another variable, such as terms of climate and noise on regulation of pedestrian path. (2) The research use qualitative method supported by the spread of questioner in the aspect of comfort pedestrian of pedestrian paths. (3) The regulation of this research based on requirements and rule of Minister PU No. 03/PRT/M/2014, it can develop with add result analyze by users on the regulation of pedestrian path. (4) It is expected to government add the rules of regulation city at Berastagi district so that is not use pedestrian path for personal benefit such as stores are too obverse that cause narrow for pedestrian path.

\section{ACKNOWLEDMENT}

This article is writen by research who are partly funded by Universitas Sumatera Utara and was given out as a donation to the goverment in order to preserve and improve the value of design, local wisdom, arts and ethnic.

\section{REFERENCES}

[1] Rustam, H. (2003) Komponen Perancangan Arsitektur Lansekap. Jakarta: Bumi Aksara.

[2] M. U. Pekerjaan (2014) Peraturan Menteri Pekerjaan Umum Nomor 03/PRT/M/2014 Tentang Pedoman Perencanaan Sarana Jaringan Pejalan Kaki di Kawasan Perkotaan.

[3] Iswanto (2006) "Pengaruh Elemen-elemen Pelengkap Jalur edestrian Terhadap Kenyamanan Pejalan Kaki," Artikel Jurnal Ilmiah perancangan Kota dan Pemukiman, pp. 21-29. 